\title{
RESEARCH OF INFORMATION MAINTENANCE TECHNOLOGY OF MACHINE OPERATOR TRAINING QUALITY ASSESSMENT AS THE ELEMENT OF THE SYSTEM
}

\author{
Alexander Laktionov \\ Department of Automation and Electric Drive \\ Poltava National Technical Yuri Kondratyuk University \\ 24 Pershotravnevyi ave., Poltava, Ukraine, 36011 \\ laktionov.alexander@ukr.net
}

\begin{abstract}
The information maintenance technology of machine operator training quality assessment with numerical programmed control (the machine operator), which ensures the operation of the "Operator - Machine Tool - Part Manufacturing Program" (OMMP) system, has been studied. The methods used to obtain primary empirical self-assessments, expert assessment and standardized estimates of the industry standard for calculating:

1) The index of professional competence of the machine operator, where self-assessments and expert assessments are combined;

2) The index of quality assessment of machine operator training, where the series of expert assessments and standardized assessments of the industry standard are combined, separately, for each of the four levels of complexity of the part-processing control program.

The proposed mathematical methods of index estimates simplify the process of comparative analysis and establish a relationship between the growth index of the professional machine operator competence formation and the effectiveness of the information maintenance technology index for assessing the quality of its training by state certification methods.

It has been experimentally proved that raising the level of qualification through the means of state certification has a significant effect on the growth of the level of professional competence and the quality of machine operator training. The effectiveness of information technology to support the quality assessment of machine operator training is provided by subjective factors (formed qualities of the operator's personality) in conjunction with the external (objective) factors causing them to form.
\end{abstract}

Keywords: professional competence, quality of machine operator training, open system, self-assessments, expert assessments, standardized assessments.

\section{Introduction}

Information Technology (IT) to support the assessment of the quality of machine operator training as an OMMP element in the production sphere - is a set of methods and procedures by which the functions of collection, transmission, processing, storing and communicating to the user information in organizational and management systems with the selected complex of technical means [1].

A machine operator with computerized numerical control (CNC) is a machine operator, a "worker working on a machine tool" [2].

Information technology, which provides an increase in the machine operator training quality, is an indicator of the effectiveness of the use of a complex of diagnostic, mathematical and formative methods, actualizing research. The experience of using existing methods for assessing the training quality of machine workers indicates the absence of a systemic assessment of the interaction of the qualities of a person's professional competence (subjective factors) and the objective factors causing them.

The scheme of ensuring the effectiveness of information maintenance technology for assessing the quality of machine operator training is shown in Fig. 1. 


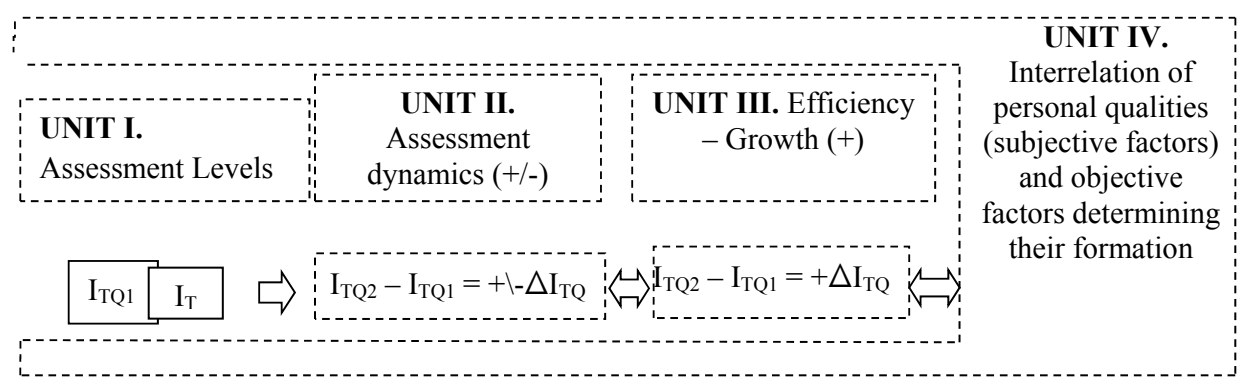

Fig. 1. The scheme of the effectiveness of providing information maintenance technology for machine operator training quality assessment

BLOCK I. Levels (Numerical Values of the Index - $\mathrm{I}_{\mathrm{TQ}}$ ) of information maintenance technology for machine operator training quality assessment as an element of the social (C) subsystem, which functions only in conjunction with the technical (Ti) and information (Ii) subsystems of the OMMP system.

BLOCK II. Dynamics (+/-) of the quality of machine operator training is an indicator of the formed qualities of personality, the content of which is subordinated to the general ultimate goal (result) of the functioning of the OMMP system.

BLOCK III. Efficiency is a significant increase $(+)$ of the indicator of information maintenance technology for machine operator training quality assessment, which is provided by subjective factors (the formed qualities of the operator's identity) in co-operation with the factors that determine their formation by external (objective) factors.

BLOCK IV. Interrelation of formed personality qualities (subjective factors) and causing objective factors in the process of state attestation of the machine operator.

The effectiveness of the information maintenance technology for machine operator training quality assessment of the basic sample (c) in the comparative study is fixed using the formula of the mean square deviation of the empirical values of the index estimates (1):

$$
\Delta \overline{\mathrm{I}}=\sqrt{\frac{\sum_{\mathrm{k}=1}^{\mathrm{n}}\left(\mathrm{I}_{2}(\mathrm{k})-\mathrm{I}_{1}(\mathrm{k})\right)^{2}}{\mathrm{n}}},
$$

where $I_{1}$ - empirical numerical values of the index estimates of the machine operator $I_{i}$ in open mixed systems of the first diagnostic slice; $\mathrm{I}_{2}$ - empirical numerical values of the index estimates of the machine operator $I_{i}$ in open mixed systems of the next (second) diagnostic slice; $k$ - ordinal number of the empirical value of the index estimates of the machine operator, which is included in the current basic research sample $(n=34)$.

\section{Literature review and problem statement}

The basis of information maintenance technology for machine operator training quality assessment is the formation of competencies that characterize the content of the professional competence of the individual: "it is the aggregate of abilities, purposefulness, resolve and willingness of the subject to a qualified constructive activity, realized in practical activity" [3]. The study of the quality of machine operator training involves the study of its professional competence by methods of self-assessment and expert assessments using a common list of indicators and a ranking scale.

Professional competence characterizes the degree of competence in the practical activity of the machine operator, "competence is an assessment of the achievement (or non-achievement) of this norm" [4]. The proposed scheme for determining the professional competence of a specialist relies on the interaction of diagnostic methods of acquired knowledge, skills and abilities (self-assessment methods) and products of practical activity (methods of expert assessment). Scientists [5] are studied the influence of the personality traits of a specialist on the results of practical activity, but do not use methods of combining self-assessments and expert assessments. 
The professional competence of the machine operator can be considered as:

1) integrative concept, which includes a set of constituents (mobility of knowledge, alternatives to the method of activity, critical thinking);

2) system of components (social, special, individual);

3) combination of components (training and key competencies);

4) composition of integrated knowledge, skills, abilities, and the like;

5) knowledge in action, social and personal experience in a particular field;

6) qualitative and quantitative characteristics of the personality properties "[6].

In the structure of the concept of professional competence of a specialist, researchers are obliged to identify certain components which content is differentiated and specified by their indicators. In our study, the "professional competence of the machine operator", which is an element of the OMMP system, is defined as an integral characteristic of the interaction of gnostic, motivational and productive components which interconnections describe the integrity of his personality.

When modeling mathematical methods for assessing the quality of machine operator training, let's adhere to the algorithm definition: "Training quality is commonly understood as the correspondence of a specialist's training level to the requirements of a professional environment in which he has to work" [7]. The model of this study involves obtaining a series of self-assessments, expert assessments and standardized assessments, but does not imply their combination, hinders the study of the dependence of the level of professional competence and the quality of specialist training [8]. Over the past decade, researchers have been actively proposing mathematical models for assessing the professional skills of workers in conjunction with employer ratings [9]. When studying the relationship between assessments of the quality of specialist training and professional competence in the political sphere [10], scientists come to the conclusion: "By creating standardized work instructions, it becomes easy to assess the process and make sure that work tasks are performed at the right level of quality" [11]. The use of self-assessments, expert assessments and standardized assessments in accordance with standardized requirements for assessing the quality of a specialist's training makes it possible to consider it in conjunction with the level of development of its professional competence under the influence of formative methods.

Improving the training quality increases the efficiency of information technologies of the production process, which is studied in $[12,13]$. Scientists investigate mathematical methods that take into account, besides the objective characteristics of the personality, other characteristics of the technical and informational subsystems. This makes it possible to use simulators based on information systems in the production process [14-17].

Our study uses a validated single list of indicators and a typical ordinal scale to obtain a series of self-assessments, expert assessments and standardized assessments, on the basis of which mathematical calculation models are developed: the machine operator's professional competence index and the quality assessment index of its training as an element of an open mixed OMMP system.

\section{Mathematical modeling of index estimation}

The index of professional competence of the machine operator $\left(\mathrm{I}_{\mathrm{PC}}\right)$ is calculated on the basis of a series of self-assessments and expert assessments using a single list of indicators and a single-type ordinal scale of assessment.

The information technology index for ensuring the assessment of the quality of machine operator training $\left(\mathrm{I}_{\mathrm{TQ}}\right)$ is calculated using two series of assessments - expert ratings and standardized assessments of the industry standard, obtained on the basis of a single list of indicators.

The study of the influence of state attestation methods on increasing the level of professional competence and the quality assessment of the training of machine operators, who have increased their qualification rank, was conducted on the basis of a specially selected sample of subjects. To study the dependencies between the index estimates of the machine operators of this sample, a well-grounded set of mathematical statistics methods was used: the Shapiro-Wilk criterion; average sample values, sample dispersions, mean square deviations, sample linear correlation coefficient, approximation error, elasticity coefficient, determination coefficient, F-criterion, Student's t-test [18]. 


\section{Research results of information maintenance technology of machine operator training quality assessment}

In the study of information maintenance technology of machine operator training quality assessment a single list of indicators of personal professional competence was used, the specific weight of which was deducted by the methods of average sample values of expert assessments and their ranking [19]. The content of the selected 18 indicators is formulated in accordance with the requirements of the ISO 18529 standard "Ergonomics - Ergonomics of human-system interaction - description of human-oriented life cycle processes” [20], (Table 1).

\section{Table 1}

Components and indicators of professional machine operator competence

Indicators of professional machine operator competence and specific gravity $\left(B_{i}\right)$

Indicators of the gnostic component

1 - use of a complex of various tools for machining parts on a CNC machine (0.176)

2 - selection of modes of processing parts on the control panel of various CNC machines $(0.165)$

3 - Starting and processing parts of various types of complexity on a CNC machine (0.173)

4 - Adjusting shaft alignment using precision measurement tools for machining parts on a machine (0.17)

5 - providing various classes of precision machining of parts on a CNC machine (0.163)

6 - Programming on the control panel of CNC machines with one spindle and different number of axes $(0.151)$

\section{Indicators of the motivational component}

7 - Improving the sensory-motor response to accelerate work on the binding of the "zero" of the part to the X-axis $(0.17)$

8 - Fulfillment of regulatory requirements for precision machining of parts on a CNC machine (0.166)

9 - focusing on typical diagrams of the trajectory of the cutter in the process of machining parts on a CNC machine $(0.171)$

10 - Programming processing of volumetric parts on machines with various

coordinates $(0,156)$

11 - Experience of using tools that are fixed in the turret $(0.177)$

12 - The use of various signal transmission systems of the quality of part processing (leading, optical and radio) during the operae tion of the CNC machine (0.158)

\section{Indicators of the productive component}

13 - Control the successive stages of processing parts on different coordinate machines $(0.173)$

14 - Measure spatial dimensions of parts with different coordinate axes using digital display devices (0.183)

15 - Program the machining of parts on the control panel of the CNC machine, which has one or more spindles $(0.159)$

16 - Use measuring devices with a high degree of accuracy (0.162)

17 - Set the zero point of the tool when setting up the work of the machine $(0.163)$

18 - Use measuring devices of varying complexity $(0.158)$

The obtained series of assessments (self-assessments, expert assessments and standardized assessments of industry standard requirements), using a single list of indicators of professional competence, are used to calculate the index estimates of the formation of professional competence of the machine operator $\left(\mathrm{I}_{\mathrm{PC}}\right)$, which is an element of the social subsystem of the OMMP system, and information maintenance technology of machine operator training quality assessment $\left(\mathrm{I}_{\mathrm{TQ}}\right)$.

The index of professional competence of the machine operator $\left(\mathrm{I}_{\mathrm{PC}}\right)$ is based on the content of the three components of the integrated numerical coefficients $\left(\mathrm{K}_{\mathrm{G}}, \mathrm{K}_{\mathrm{M}}, \mathrm{K}_{\mathrm{F}}\right.$ - gnostic, motivational and final components), where each is calculated separately by combining two series of empirical estimates obtained using a single list of indicators: self-assessments $\left(\mathrm{A}^{\mathrm{s}}\right)-\mathrm{x}_{1}, \mathrm{x}_{2}, \mathrm{x}_{3}, \ldots, x_{\mathrm{n}}$; expert assessments $\left(A^{\mathrm{e}}\right)-\mathrm{y}_{1}, \mathrm{y}_{2}, \mathrm{y}_{3}, \ldots, \mathrm{y}_{\mathrm{n}}$ using the model of formula (2), known as the Lebedik index [19]:

$$
\mathrm{K}=0,5+\frac{9 \mathrm{~A}^{\mathrm{e}}}{10+3 \chi^{2}}
$$

where $\left(\mathrm{A}^{\mathrm{e}}\right)$ - total indicator of expert assessments of the i-th number of the corresponding indicator: 


$$
\mathrm{A}^{\mathrm{e}}=\sum_{\mathrm{i}=1}^{\mathrm{n}} \mathrm{y}_{\mathrm{i}} \mathrm{B}_{\mathrm{i}}
$$

$n$ - the number of indicators; $\mathrm{B}_{\mathrm{i}}$ - specific weight coefficient of the $\mathrm{i}$-th indicator, a $\sum_{\mathrm{i}=1}^{\mathrm{n}} \mathrm{B}_{\mathrm{i}}=1$; $\chi^{2}$ - generalized indicator of the total disagreement between the series of self-assessments of the operator $\left(\mathrm{A}^{\mathrm{s}}\right)-\mathrm{x}_{1}, \mathrm{x}_{2}, \mathrm{x}_{3}, \ldots, \mathrm{x}_{\mathrm{n}}$ and expert assessments $\left(\mathrm{A}^{e}\right)-\mathrm{y}_{1}, \mathrm{y}_{2}, \mathrm{y}_{3}, \ldots, \mathrm{y}_{\mathrm{n}}$, which is calculated by the formula:

$$
\chi_{1}^{2}=\sum_{i=1}^{n} \frac{\left(x_{i}-y_{i}\right)^{2}}{\left(x_{i}+y_{i}\right)} \cdot B_{i}
$$

The index of professional competence of the machine operator $\left(\mathrm{I}_{\mathrm{PC}}\right)$ combines the three components of the integrated numerical factors $-\mathrm{K}_{\mathrm{G}}, \mathrm{K}_{\mathrm{M}}, \mathrm{K}_{\mathrm{F}}$ (gnostic, motivational and final, each of which combines 6 indicators) and calculated using the formula (3):

$$
\mathrm{I}_{\mathrm{PC}}=\sqrt[3]{\mathrm{K}_{\mathrm{G}} \cdot \mathrm{K}_{\mathrm{M}} \cdot \mathrm{K}_{\mathrm{F}}},
$$

where $\mathrm{K}_{\mathrm{G}}, \mathrm{K}_{\mathrm{M}}, \mathrm{K}_{\mathrm{F}}$ - empirical numerical values of the integrated coefficients of the gnostic, motivational and final components.

The index of information maintenance technology of machine operator training quality assessment $\left(\mathrm{I}_{\mathrm{TQ}}\right)$ is determined based on the calculation of the three component coefficients $\left(\mathrm{K}_{\mathrm{G}}, \mathrm{K}_{\mathrm{M}}, \mathrm{K}_{\mathrm{F}}\right)$. Each coefficient is separately calculated by combining two rows of assessments obtained using a single list of indicators and a single-type ordinal assessment scale: experts' assessments $\left(\mathrm{A}^{\mathrm{e}}\right)-\mathrm{y}_{1 \mathrm{i}}, \mathrm{y}_{2 \mathrm{i}}, \mathrm{y}_{3 \mathrm{i}}, \ldots, y_{\mathrm{ni}}$; and normalized assessments of the requirements of the industry standard $\left(\mathrm{A}^{\mathrm{st}}\right),-\mathrm{c}_{1 \mathrm{i}}, \mathrm{c}_{2 \mathrm{i}}, \mathrm{c}_{3 \mathrm{i}}, \ldots \mathrm{c}_{\mathrm{ni}}$.

These two series of expert and industry standard assessments are combined into an integrated numerical factor, separately, for the gnostic, motivational, and effective personality components of a machine operator using formula (4) with [19]:

$$
\mathrm{K}=0,5+\frac{9 \mathrm{~A}^{\mathrm{e}}}{10+3 \chi^{2}}
$$

where $A^{e}=\sum_{i=1}^{n} y_{i} B_{i}$ - generalized indicator of expert assessments of the n-th CNC machine operator, obtained on the basis of a single list of 18 indicators (i); $n$ - the number of operators of CNC machines; $B_{i}$ - specific weight coefficient of the $i$-th parameter (indicator), a $\sum_{i=1}^{n} B_{i}=1 ; \chi^{2}$-generalized indicator of the total disagreement between the Standard $\left(\mathrm{A}^{\mathrm{st}}\right)$ and expert assessments $\left(\mathrm{A}^{\mathrm{e}}\right)$, which is calculated by the formula:

$$
\chi_{1}^{2}=\sum_{i=1}^{n} \frac{\left(c_{i}-y_{i}\right)^{2}}{\left(c_{i}+y_{i}\right)} \cdot B_{i}
$$

The quality assessment index of machine operator training $\left(\mathrm{I}_{\mathrm{PC}}\right)$ combines the three components of the integrated numerical coefficients - gnostic $\left(\mathrm{K}_{\mathrm{G}}\right)$, motivational $\left(\mathrm{K}_{\mathrm{M}}\right)$ and the final $\left(\mathrm{K}_{\mathrm{F}}\right)$ components and is calculated using the formula (5):

$$
\mathrm{I}_{\mathrm{TQ}}=\sqrt[3]{\mathrm{K}_{\mathrm{G}} \cdot \mathrm{K}_{\mathrm{M}} \cdot \mathrm{K}_{\mathrm{F}}}
$$

To conduct a comparative analysis in order to verify the influence of state certification on the growth of the level of formation of professional competence of the machine operator in conjunction with the machine operator training quality assessment, based on the created model of the 
General population of 419 open mixed systems of machine-building enterprises in the cities of Karlovka, Poltava and Kharkiv a representative sample of machine operators of 34 OMMP systems who have successfully upgraded their qualification rank with according to the requirements of state certification was formed for comparative research

By the method of comparative analysis of the sets of index estimates of two diagnostic sections, let's determine the significant growth of empirical numerical indicators of the professional competence indices of the machine operator sample (Fig. 2).

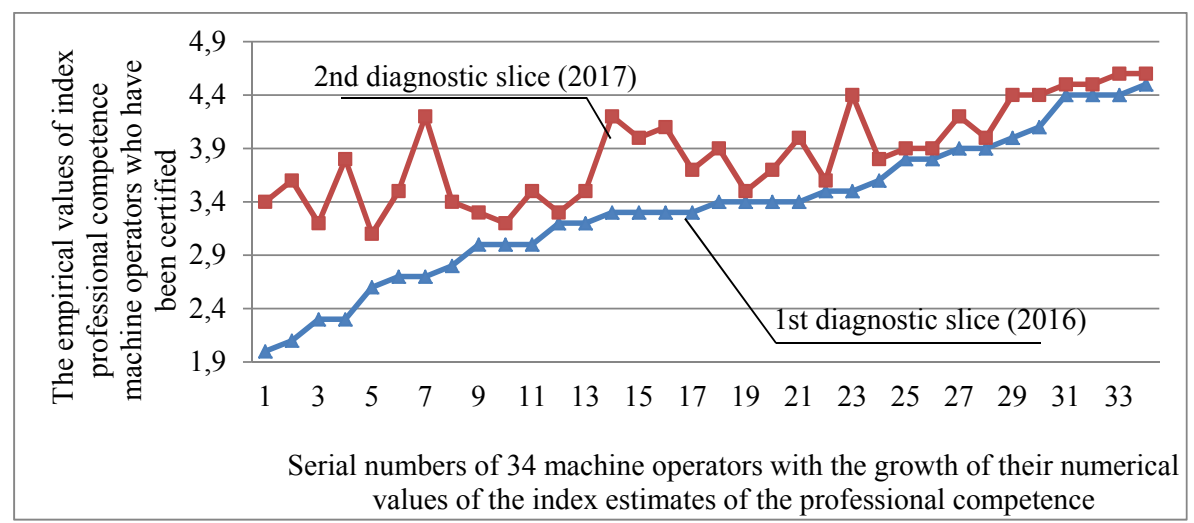

Fig. 2. Comparative analysis of the levels of professional competence of machine operators of 34 OVCP systems that have been certified by the state - two diagnostic slices: 2017 and 2016

The results of a comparative analysis of changes in the indices of professional competence formation for the sample of machine operators $(n=34)$ using the methods of mathematical statistics, Table 2.

Table 2

Comparative analysis of the index estimates of professional competence formation for the sample of machine workers ( $\mathrm{n}=34$, diagnostic slices: 2017 and 2016)

\begin{tabular}{ccccccccc}
\hline$\overline{\mathbf{I}}_{\mathbf{P C} 1}$ & $\overline{\mathbf{I}}_{\mathrm{PC} 2}$ & $\mathbf{S}^{2}\left(\mathbf{I}_{\mathbf{P C} 1}\right)$ & $\mathbf{S}^{2}\left(\mathbf{I}_{\mathbf{P C} 2}\right)$ & $\mathbf{t}_{\text {emp }}$ & $\mathbf{T}_{\text {cr }}(\mathbf{0 , 0 5})$ & $\mathbf{W}, \mathbf{2 0 1 6}$ & $\mathbf{W}, \mathbf{2 0 1 7}$ & $\mathbf{W}(\boldsymbol{\alpha}=\mathbf{0 , 0 5}) \mathbf{c r}$ \\
\hline 3,33 & 3,85 & 0,43 & 0,19 & 30,8 & 2,021 & 0,97 & 0,953 & 0,933
\end{tabular}

According to the results of the 2nd diagnostic slice, the level of professional competence of machine operators increased due to subjective factors - the quality of professional competence of the individual, formed by state certification methods (objective factors). Improving the qualification category of machine operators with state certification tools has intensified its social and practical activities in cooperation with higher performance CNC machines (technical subsystem) and control programs for manufacturing parts on a $\mathrm{CNC}$ machine with a higher level of complexity (information subsystem) of the OMMP system.

Thus, it has been experimentally proven that raising the level of qualification discharge by means of state attestation significantly influences the growth of the index score for the formation of professional competence of the machine operator as an element of the OMMP system.

The growth of the efficiency index of information technology to support the assessment of the training quality for machine operators is the determination of significant changes in empirical numerical values of the index estimates of two diagnostic measurements, which is graphically shown in Fig. 3.

Research results of changes in information maintenance technology indexes of training assessment for 34 machine operators (2017, compared to 2016) using the methods of mathematical statistics, Table 3 


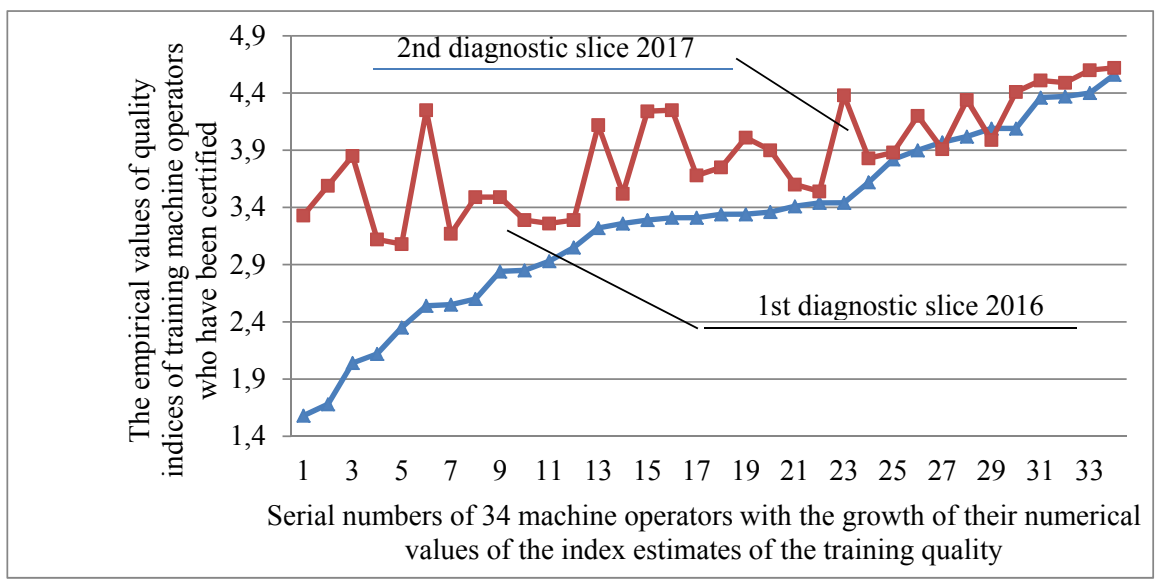

Fig. 3. Comparative analysis of the index estimates of the training quality of a sample of 34 machine operators that have been certified

Table 3

Comparative analysis of the index estimates of machine operator training quality (Sample $n=34$ ) - two diagnostic sections: 2017 and 2016

\begin{tabular}{ccccccccc}
\hline$\overline{\mathbf{I}}_{\mathrm{TQ1}}$ & $\overline{\mathbf{I}}_{\mathrm{TQ2} 2}$ & $\mathbf{S}^{2}\left(\mathbf{I}_{\mathrm{TQ} 1}\right)$ & $\mathbf{S}^{2}\left(\mathbf{I}_{\mathrm{TQ} 2}\right)$ & $\mathbf{t}_{\text {emp }}$ & $\mathbf{T}_{\text {cr }}(\mathbf{0 , 0 5})$ & $\mathbf{W}, \mathbf{2 0 1 6}$ & $\mathbf{W}, \mathbf{2 0 1 7}$ & $\mathbf{W}(\boldsymbol{\alpha}=\mathbf{0 , 0 5}) \mathbf{c r}$ \\
\hline 3,26 & 3,85 & 0,59 & 0,21 & 3,78 & 2,021 & 0,965 & 0,956 & 0,933
\end{tabular}

According to the results of the 2nd diagnostic slice (2017), compared to the 1st slice (2016), the change in the index estimates of information maintenance technology of training machine operator training quality assessment is due to the level of professional competence of the personality, due to objective factors, in particular certification

Improving the qualification category of machine operators with state certification contributes to the growth of his achievements in using types of CNC machines with higher productivity (technical subsystem) and control programs for processing parts of higher levels of complexity (information subsystem) of the OMMP system.

The growth of the effectiveness of information maintenance technology of training machine operator training quality assessment due to factors influencing the conditions of the socio-economic environment, organized training and self-study, the cooperation of the machine operator with the specialists of its field of activity.

According to the results of the 2nd diagnostic slice (2017), there is a significant increase in the numerical values of the information technology indexes supporting the assessment of the quality of the training of the 6th, 13th, 15th, 16th, 23rd machine operators, which is explained by their translation for the maintenance of CNC machine tools with a higher type of productivity and accumulated experience of using the control program of processing parts on a CNC machine with a higher level of complexity.

The interaction of index estimation of the formation of professional competence of an individual and information maintenance technology to support training quality for a sample of machine operators who successfully increased their qualification rank was studied using the methods of the linear function of a pair regression (Fig. 4).

The results of the comparative study indicate that in the production process, the effectiveness of information technology to support the quality assessment of machine operators, as is elements of the OMMP system, is ensured by direct growing interaction with the level of the professional competence formation of the individual.

Thus, it has been experimentally proved that the increase in the index of the formation of the professional competence of a machine operator by means of state certification ensures interaction 
with the growing effectiveness of information technology supporting the assessment of the quality of professional training and the development of a personality.

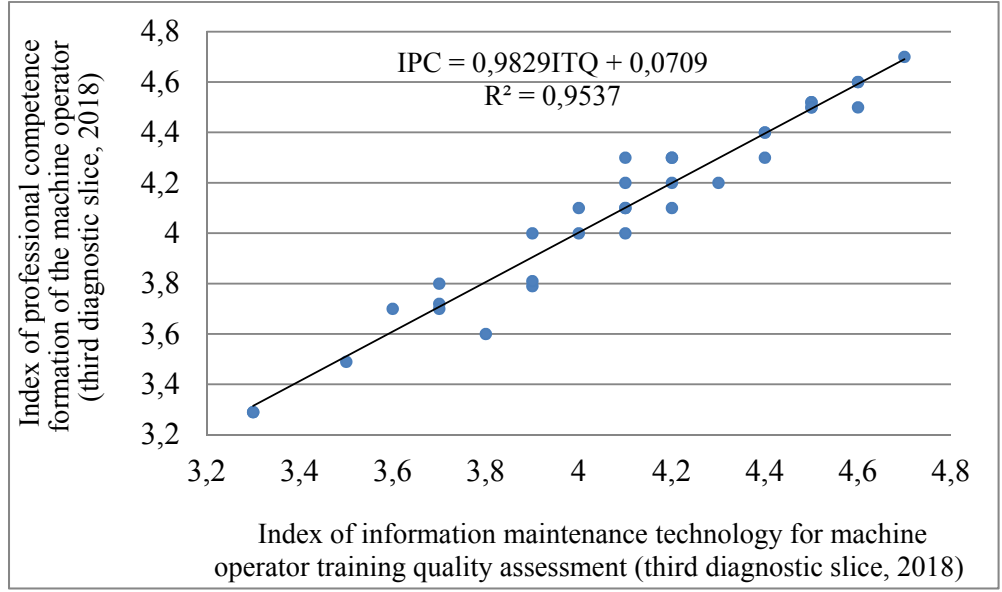

Fig. 4. The relationship of the professional competence formation $\left(\mathrm{I}_{\mathrm{PC}}\right)$ and information maintenance machine operator training quality assessment $\left(\mathrm{I}_{\mathrm{TQ}}\right)$

Research results of the existence of strong dependencies of the linear pair regression function using the methods of mathematical statistics are shown in Table 4.

Table 4

Research results of the linear pair regression function

\begin{tabular}{|c|c|c|c|c|c|c|c|c|c|c|}
\hline \multicolumn{11}{|c|}{ Research results of the linear function: $\mathrm{I}_{\mathrm{PC}}=0,961 \mathrm{I}_{\mathrm{TQ}}+0,153$} \\
\hline Research indicator & $\overline{\mathrm{I}}_{\mathrm{TQ}}$ & $\overline{\mathrm{I}}_{\mathrm{PC}}$ & $\mathrm{S}^{2}\left(\mathrm{I}_{\mathrm{TQ}}\right)$ & $\mathrm{S}^{2}\left(\mathrm{I}_{\mathrm{PC}}\right)$ & $\mathrm{S}\left(\mathrm{I}_{\mathrm{TQ}}\right)$ & $\mathrm{S}\left(\mathrm{I}_{\mathrm{PC}}\right)$ & $\mathrm{r}_{\mathrm{I}_{\mathrm{TQ}} \mathrm{I}_{\mathrm{PC}}}$ & $\overline{\mathrm{A}}$ & $\mathrm{b}$ & $\mathrm{a}$ \\
\hline Received value & 4,1 & 4,1 & 0,14 & 0,14 & 0,37 & 0,37 & 0,97 & 1,4 & 0,983 & 0,07 \\
\hline \multicolumn{11}{|c|}{ (Continuation of the table) } \\
\hline Research indicator & $\overline{\mathrm{E}}$ & $\mathrm{R}^{2}$ & $\mathrm{~F}_{\text {table }}$ & $\mathrm{F}_{\text {act }}$ & $\mathrm{T}_{\text {crit }}$ & $t_{b}$ & $\mathrm{t}_{\mathrm{a}}$ & & & \\
\hline Received value & 0,98 & 0,95 & 4,08 & 659,4 & 2,02 & 25,6 & 0,45 & & & \\
\hline
\end{tabular}

\section{Discussion of the results of the effectiveness of information maintenance technology of ma- chine operator training quality assessment}

A comparative analysis of the dynamics of index estimates, combining a series of self-assessments, expert assessments and standardized assessments of the requirements of the industry standard, is a method of information technology to support the assessment of the training quality machine operators.

The effectiveness of information maintenance technology of machine operator training quality assessment is a significant increase in the index scores of a person's professional competence and the quality of machine operator training, which is ensured by the interaction of formative, diagnostic and mathematical methods.

Mathematical methods of index assessment allow to identify the degree of consistency/ imbalance of consciousness (self-assessment) and social and practical activities of the machine operator (expert assessment), which is a necessary condition for improving the selection of workers with higher qualification levels. 


\section{Conclusions}

The basis of the formula model of the information maintenance technology of the support for assessing the training quality for a machine operator is combination of the assessments of its experts and standardized estimates, which provide industry standards. To calculate the empirical numerical value of the index of the formation of the professional competence of the machine operator, methods of combining self-assessments and expert assessments are used.

The proposed mathematical methods for calculating index estimates simplify the process of comparative analysis and improve accuracy in assessing the formation of the professional competence of the machine operator and the quality of his professional training by means of state attestation.

It has been established that the growth of the professional competence index of machine operators of a representative sample of 0.79 times or 1.15 times correlates with the growth of the information maintenance technology index for assessing the training quality of a machine operator by +0.67 times or 1.17 times.

With the growth of the index levels of professional machine operator competence $\left(\mathrm{I}_{\mathrm{PC}}\right)$ and the quality of its training $\left(\mathrm{I}_{\mathrm{TQ}}\right)$, there is a direct growing interaction between them, which indicates an increase in the effectiveness of information maintenance technology of machine operator training quality assessment by state certification methods.

\section{References} KNEU, 315

[1] Denisova, O. O. (2003). Informatsiyni systemy i tekhnolohiyi v yurydychniy diyalnosti. Kyiv:

[2] Slovnyk ukrainskoi movy. V 11 t. (1970-1980). Kyiv: Naukova dumka.

[3] Frolova, I. (2010). Kachestvo podgotovki specialista kak konkurentnoe preimushchestvo vuza. Naberezhnye Chelny, 124.

[4] Holovan, M. S. (2008). Kompetentsiya i kompetentnist: Dosvid teoriyi, teoriya dosvidu. Vyshcha osvita Ukrainy: Teoretychnyi ta naukovo-metodychnyi chasopys, 3, 23-30.

[5] Hakim, A. (2015). Contribution of Competence Teacher (Pedagogical, Personality, Professional Competence and Social) on the Performance of Learning. The International Journal of Engineering and Science (IJES), 4 (2), 1-12.

[6] Nizovtsev, A. V. (2013). Rozrobka modeli profesiynoi kompetentnosti inzhenera. Pedahohichni nauky: teoriya, istoriya, innovatsiyni tekhnolohiyi, 8, 243-255.

[7] Dresher, Yu. N. (2012). Kak ocenit' kachestvo podgotovki specialistov. Obrazovatel'nye tekhnologi, 2, 80-91.

[8] Bernhard, A. (2012). Quality Assurance in an International Higher Education Area. Springer, 300. doi: https://doi.org/10.1007/978-3-531-94298-8

[9] Michelli, N. M., Dada, R., Eldridge, D., Tamim, R. M., Karp, K. (Eds.). (2016). Teacher Quality and Teacher Education Quality: Accreditation from a Global Perspective. Routledge, 262. doi: https:// doi.org/10.4324/9781315669496

[10] Mansvelt, J., Suddaby, G., O’Hara, D., Gilbert, A. (2009). Professional development: assuring quality in e-learning policy and practice. Quality Assurance in Education, 17 (3), 233-249. doi: https:// doi.org/10.1108/09684880910970641

[11] Nishad, N. H. (2018). Impact of Process Standardisation on Performance \& Potential Output of Fresh Operators. International Journal of Textile Science, 7 (1), 27-34.

[12] Abri, A. G., Mahmoudzadeh, M. (2014). Impact of information technology on productivity and efficiency in Iranian manufacturing industries. Journal of Industrial Engineering International, 11 (1), 143157. doi: https://doi.org/10.1007/s40092-014-0095-1

[13] Acar, A. Z., Uzunlar, M. B. (2014). The Effects of Process Development and Information Technology on Time-based Supply Chain Performance. Procedia - Social and Behavioral Sciences, 150, 744-753. doi: https://doi.org/10.1016/j.sbspro.2014.09.044

[14] Posadska, I. S. (2017). Modeli ta metody strukturyzatsiyi kontentu ta kontrolnykh testiv v systemakh avtomatyzovanoho navchannia. Chernihiv, 22. 
[15] Chernov, V. G., Pavlenko, M. A., Tymochko, A. I., Svistunov, D. Yu., Koroluk, N. A. (2014). Method of forming set individual test tasks for assessment level of operator training acs during simulator training. Systemy upravlinnia, navihatsiyi ta zviazku, 2, 75-80.

[16] Knyazev, V. A. (2005). Tekhnologiya ocenki urovnya deyatel'nosti operatorov v chelovekomashinnyh sistemah. Moscow, 59.

[17] SHana, M. (2014). Avtomatizirovannaya informacionnaya sistema adaptivnogo obucheniya na osnove kompetentnostnogo podhoda. Nal'chik, 182.

[18] Kobzar', A. I. (2006). Prikladnaya matematicheskaya statistika. Moscow: Fizmatlit, 816.

[19] Lebedyk, M. P. (2003). Tekhnolohiya atestatsiyi tsilisnoho rozvytku osobystosti na osnovi otsinok sotsialnoi zrilosti uchasnykiv pedahohichnoho protsesu. Poltava: RVV PUSKU, 305.

[20] ISO/TR 18529:2000. Ergonomics - Ergonomics of human-system interaction - Human-centred lifecycle process descriptions (2000). International Organization for Standardization, 28.

\title{
PROACTIVE DEVELOPMENT OF ORGANIZATIONAL STRUCTURE OF TERRITORIAL DEVELOPMENT PROJECT WITH USING BI-ADAPTIVITY
}

\author{
Alexander Timinsky \\ Department of management technologies \\ Taras Shevchenko National University of Kyiv \\ 64/13 Volodymyrska str., Kyiv, Ukraine, 01601 \\ timin@ukr.net \\ Illia Marushchak \\ Department of Business Administration and Project Management \\ University of Economics and Law «KROK» \\ 30-32 Tabirna str., Kyiv, Ukraine, 03113 \\ ilya.old@meta.ua
}

\begin{abstract}
The article presents the scientific task of developing models and methods of proactive development of the organizational structure of territorial development projects using bi-adaptivity. Literary sources are analyzed. There are two types of organizational structures - the organizational structure of the territorial development project and the organizational structure of the territorial network, created in the project. The similarity of such structures is noted. The aspects of the organizational structure, for which it is necessary to develop models of proactive development, are selected and analyzed. This is the entrepreneurial form of the territorial network, the type of organizational structure and the system of communications of the organizational structure of the territorial network with the organizational structure of the parent enterprise. The concept of the gradient of the territorial development of the industries has been introduced, its definition has been given. The method of proactive development of the organizational structure in the project of territorial development is proposed. The content of the method of configuring the bi-adaptive system for the appearance of new types of projects is determined. The indicated results extend the scientific tools of project and program management.
\end{abstract}

Keywords: proactivity, bi-adaptivity, territorial development project, organizational structure.

\section{Introduction}

The development of enterprises and organizations in the current turbulent environment involves active project activities. In this regard, enterprises are forced to become project-oriented and implement development projects. One of the most important classes of such projects is the projects of territorial expansion related to the opening of new branches, the development of a network of institutions (representations) and the provision of organizational (commercial) presence 